\title{
( \\ THE ANALYSIS OF ENTREPRENEURIAL ACTIVITY OF STUDENTS OF PROFESSIONAL STUDIES
}

\author{
PUPAVAC, D[rago]
}

\begin{abstract}
In Croatia there are more female than male students at the departments of economics and entrepreneurship. However, male total entrepreneurial activity (TEA) rates are substantially higher than female TEA rates. The research hypothesis is that the desire for entrepreneurial activity is greater in those who personally know someone who has its own business. The main goal of the research was to establish whether gender moderates the link between personal acquaintance with the entrepreneur and total entrepreneurial activity. The research results have confirmed that the students of professional studies of Entrepreneurship who personally know an entrepreneur are more likely to take action and start their own business. It has also been shown that gender doesn't moderate the link between knowing an entrepreneur personally total entrepreneurial activity.
\end{abstract}

Key words: entrepreneurship, students, acquaintance with entrepreneurs, gender, professional studies

\section{INTRODUCTION}

In the Republic of Croatia there are more female than male students at the departments of economics and entrepreneurship where female students take up a large share (around $70 \%$ ) of university places (Statistics Year Book, 2010). In practice, however, men are more likely to have got that entrepreneurial spirit. In 2005, there were 3.79 times more men entrepreneurs than women entrepreneurs which is far above the average of GEM states [Singer, 2006]. Having not been included into any kind of entrepreneurial activity women become an economical issue, since human resources have not been thoroughly used. In entrepreneurship research, the environment is mainly seen as a determiner of success or failure (Baum, Frese \& Baron, 2007). Lack of entrepreneurial cultural background as well as antientrepreneurial way of thinking in Croatia exclude women from entrepreneurial activities (Srica, 2011). Bearing in mind that to hear about other people's experience can have an effect on us, the aim of this work is to find out how much the fact that the students of students of professional studies of Entrepreneurship know an entrepreneur personally can, from their point of view, affect their total entrepreneurial activity. We would like to see in particular if gender moderates in any way this link between personal acquaintance with the entrepreneur and overall entrepreneurial activity. In order to obtain the results the research a scientific survey method $(\mathrm{N}=56)$ and a factor analysis method have been applied. Data analysis and factor analysis were performed in Statistica program.

\section{STATISTICAL DATA}

Entrepreneurs are playing a major role in the economy of each country in the world. Entrepreneurs convert technological and organizational innovation into better products and services and motivate established competitors to improve products and services. Considering that these man and women are significant

\begin{tabular}{|c|c|c|c|c|c|c|}
\hline \multirow{2}{*}{ Sex } & \multirow{2}{*}{ No. } & \multirow{2}{*}{$\begin{array}{c}\text { Acq_E: } \\
\text { Acquaintance } \\
\end{array}$} & & \multicolumn{4}{|c|}{ TEA: Total } \\
\cline { 4 - 7 } & & Entrepreneur & $0^{\prime}$ & $1^{\prime}$ & $2^{\prime}$ & $3^{\prime}$ \\
\hline Male & 14 & 10 & 6 & 6 & 1 & 3 \\
\hline Female & 42 & 35 & 27 & 14 & 0 & 1 \\
\hline Total & 56 & 45 & 33 & 20 & 1 & 4 \\
\hline
\end{tabular}

Tab. 1. Data summary

Having graduated, plans to start his own entrepreneurial venture: 0 - No, 1 - Yes, 2 - has entrepreneurial venture shorter than 42 months, 3 - has entrepreneurial venture longer than 42 months

for the growth and development of economies in countries in which they operate their business. The results of the GEM research conducted in Croatia show that gender is a contributing factor as to when men and women become active as entrepreneurs: women are the most active between the age of 18 and 24, when they come considerably closer to men. This research also confirms that the gap between women and man is still widening, to the disadvantage of women. The research hypothesis of this study is that those who have got contacts with the entrepreneurs also express a stronger desire to start their own business. Professional studies should through different teaching methods, not only ensure but also multiply these contacts.

This point is illustrated with an observation-correlation survey (cf. Tab. 1.) to show how the fact that you know an entrepreneur personally (Acq_E: divides the results into two independent groups; those who know an entrepreneur personally and those who don't) affects total entrepreneurial activity (TEA; higher the number greater the desire to start a their own business) by male and female students (sex; two independent groups) at professional studies.

\section{RESULTS AND DISCUSSION}

First of all, we'll study closely the main effects of knowing an entrepreneur and gender on the TEA by students of professional studies. On the basis of collected data it is clear that it is very important to the students to know an entrepreneur personally before they start their own business ventures. At this point sex is not as important. This statement is confirmed by

\begin{tabular}{|c|c|c|c|c|c|}
\hline \multicolumn{6}{|c|}{ Univariate Tests of Significance for TEA (Istria1) Sigma-restricted } \\
parameterization Effective hypothesis decomposition \\
\hline & SS & $\begin{array}{c}\text { Degr. of } \\
\text { Freedom }\end{array}$ & MS & F & $\mathrm{p}$ \\
\hline Intercept & 6,56370 & 1 & 6,563699 & 14,04990 & 0,000448 \\
\hline Sex & 0,81027 & 1 & 0,810274 & 1,73443 & 0,193621 \\
\hline Acq_E & 2,17231 & 1 & 2,172309 & 4,64993 & 0,035701 \\
\hline Sexl*Acq_E & 0,36409 & 1 & 0,364090 & 0,77935 & 0,381403 \\
\hline Error & 24,29286 & 52 & 0,467170 & & \\
\hline
\end{tabular}

Tab. 2. Effects of personal acquaintance with entrepreneurs and gender on TEA data given in interaction line (Sex*Acq_E) confirms the mentioned contention (cf Tab.2.) 


\begin{tabular}{|c|c|c|c|c|c|c|c|c|}
\hline & SS & $\begin{array}{c}\text { Degr. of } \\
\text { Freedom }\end{array}$ & MS & $\mathrm{F}$ & $\mathrm{p}$ & $\eta^{2}$ & $\begin{array}{c}\text { Non- } \\
\text { centrality }\end{array}$ & $\alpha$ \\
\hline Intercept & 6,56 & 1,00 & 6,56 & 14,05 & 0,00 & 0,21 & 14,05 & 0,96 \\
\hline Sex & 0,81 & 1,00 & 0,81 & 1,73 & 0,19 & 0,03 & 1,73 & 0,25 \\
\hline Acq_E & 2,17 & 1,00 & 2,17 & 4,65 & 0,04 & 0,082 & 4,65 & 0,56 \\
\hline Sexl*Acq_E & 0,36 & 1,00 & 0,36 & 0,78 & 0,38 & 0,01 & 0,78 & 0,14 \\
\hline Error & 24,29 & 52,00 & 0,47 & & & & & \\
\hline
\end{tabular}

Tab.3. Univariate test of Significance, Effect Sizes and Powers for TEA

the results (cf. Tab. 3.) pointed to a statistically significant effect of personal acquaintance with entrepreneurs $\left(F(1,52)=4,56, p<0,05\right.$, partial $\left.\eta^{2}=0,082\right)$ on a change in total entrepreneurial activity of examinees. It can be seen from the data given in table 3 that $8,2 \%$ variance with the results of TEA can be explained by knowing an entrepreneur by students personally. How knowing an entrepreneur affects the desire to start your own business venture is shown by the Fig. 1 .

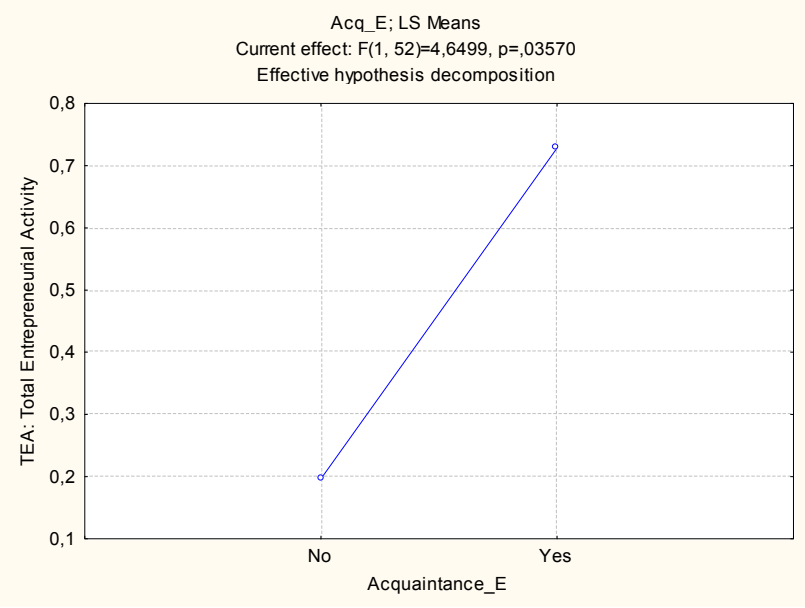

Fig. 1. Effect of acquaintance with entrepreneurs on wishing to open personal business

The examinees who don't know an entrepreneur personally show lesser entrepreneurial activity. In relation to this sex plays no role. Being male of female doesn't moderate the effects of knowing an entrepreneur on the entrepreneurial activity. This is confirmed by the interaction figure (cf. Fig. 2).

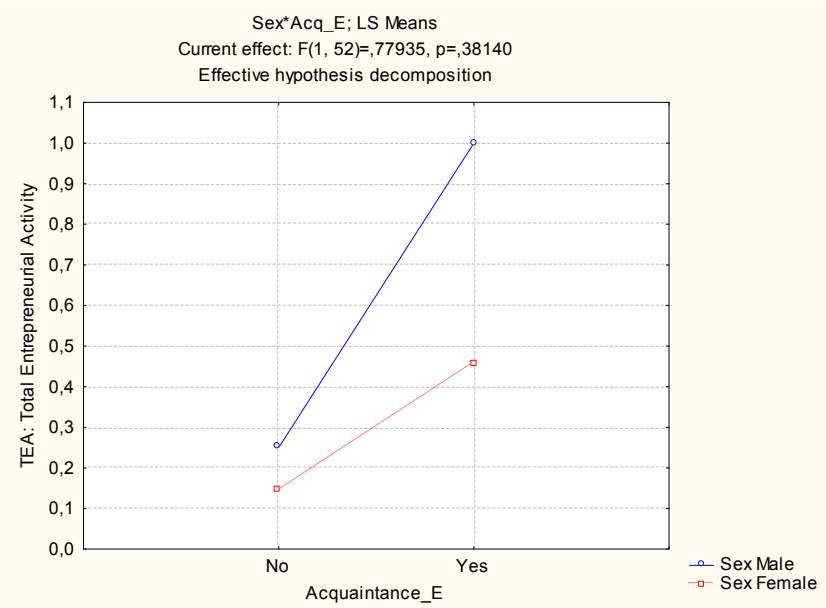

Fig. 2. Interactive graph Gender: TEA

\begin{tabular}{|c|c|c|c|c|c|c|}
\hline \multicolumn{7}{|c|}{$\begin{array}{l}\text { Bonferroni test; variable TEA (Istria1) Probabilities for Post } \\
\text { Hoc Tests Error: Between MSE }=, 46717, \mathrm{df}=52,000\end{array}$} \\
\hline & Sex & Acq_E & $\begin{array}{l}\{1\} \\
250\end{array}$ & $\begin{array}{c}\{2\} \\
1,000\end{array}$ & $\begin{array}{c}\{3\} \\
, 14286\end{array}$ & $\begin{array}{c}4\} \\
45714 \\
\end{array}$ \\
\hline & Male & No & \multicolumn{4}{|c|}{$0,4158191,0000001,000000$} \\
\hline & Male & Yes & \multicolumn{4}{|c|}{$0,0836650,186986$} \\
\hline & Female & No & \multicolumn{3}{|l|}{1,00000} & 1,000000 \\
\hline & Female & Yes & \multicolumn{4}{|c|}{$1,0000000,1869861,000000$} \\
\hline
\end{tabular}

Tab. 4. Bonferroni test

Both men and women who know an entrepreneur personally express entrepreneurial activity. Bonferroni test has shown that statistically there are no significant differences between male and female students (cf. Tab. 4.).

\section{CONCLUSION}

The Croats show tendencies to work in firms owned by the state rather than to start their own business. Women in Croatia are widely regarded as potential entrepreneurs and if encouraged and supported more than now they could become a powerful economic force in the state. In Croatia female entrepreneurs are underestimated and an average rate of entrepreneurial activity is much lower than that of men. In other words, there are four times more male entrepreneurs than female entrepreneurs. Different economic and business studies suggest completely opposite, one in four is a male student. Professional studies of entrepreneurship should not only teach how, but also enable their students to start their own business and therefore have a key role in generating and developing the entrepreneurial potential of the Republic of Croatia.

It has been confirmed in this paper that students of professional studies of entrepreneurship who know and entrepreneur personally are more likely to take action and start their own business. It has also been shown that being male or female doesn't moderate this link between knowing and entrepreneur personally and total entrepreneurial activity. In other words, the students of professional studies of entrepreneurship show no sex differences in total entrepreneurial activity. The professional studies aim to build entrepreneurial competences and their task is to ensure as well as multiply contacts between students and entrepreneurs and so to give a chance to the potential of female students to be transformed into entrepreneurial activity.

Nevertheless, this research has its limitations. It would be quite interesting to obtain the results on a much larger sample. Since more relevant results would be produced. Future research should examine if gender moderates the link between motivation to act as an entrepreneur and the overall entrepreneurship activity.

\section{REFERENCES}

Baum, J., Frese, M. \& Baron, R. (2007). The Psychology of Entrepreneurship, LEA, ISBN 0-8058-5062-7, New Jersey

Bosma, N., et. al. (2009). Global Entrepreneurship Monitor 2008 Executive Report, Babson Park, MA: Babson College, Santiago Chile: Universidad del Desarollo and London, UK: London Business School

Singer, S., et.al. (2006). Što čini Hrvatsku poduzetničkom zemljom? (What makes Croatia an entrepreneurial country? (in Croatian), Results GEM 2002-2005 for Croatia, CEPOR, ISBN 953-99154-7-3, Zagreb

Srica, V. (2011). Hrvatska 2020 - Jedna moguća budućnost (Croatia 2020 - One Possible Future (in Croatian), Profil, ISBN 978-953-319-166-9, Zagreb

*** (2010) http://www.dzs.hr - The National Statistics Institute, Statistics Year Book, Accessed on: 2011-05-20 